\title{
Front Matter: Volume 9700
}

, "Front Matter: Volume 9700," Proc. SPIE 9700, Design and Quality for Biomedical Technologies IX, 970001 (29 June 2016); doi: 10.1117/12.2229256

SPIE. Event: SPIE BiOS, 2016, San Francisco, California, United States 


\title{
PROGRESS IN BIOMEDICAL OPTICS AND IMAGING
}

\section{Design and Quality for Biomedical Technologies IX}

\author{
Ramesh Raghavachari \\ Rongguang Liang \\ Editors
}

13-14 February 2016

San Francisco, California, United States

Sponsored and Published by

SPIE 
The papers in this volume were part of the technical conference cited on the cover and title page. Papers were selected and subject to review by the editors and conference program committee. Some conference presentations may not be available for publication. Additional papers and presentation recordings may be available online in the SPIE Digital Library at SPIEDigitallibrary.org.

The papers reflect the work and thoughts of the authors and are published herein as submitted. The publisher is not responsible for the validity of the information or for any outcomes resulting from reliance thereon.

Please use the following format to cite material from these proceedings:

Author(s), "Title of Paper," in Design and Quality for Biomedical Technologies IX, edited by Ramesh Raghavachari, Rongguang Liang, Proceedings of SPIE Vol. 9700 (SPIE, Bellingham, WA, 2016) Six-Digit Article CID Number.

ISSN: 1605-7422

ISSN: 2410-9045 (electronic)

ISBN: 9781628419344

Published by

SPIE

P.O. Box 10, Bellingham, Washington 98227-0010 USA

Telephone +1 3606763290 (Pacific Time) · Fax +1 3606471445

SPIE.org

Copyright (c) 2016, Society of Photo-Optical Instrumentation Engineers.

Copying of material in this book for internal or personal use, or for the internal or personal use of specific clients, beyond the fair use provisions granted by the U.S. Copyright Law is authorized by SPIE subject to payment of copying fees. The Transactional Reporting Service base fee for this volume is $\$ 18.00$ per article (or portion thereof), which should be paid directly to the Copyright Clearance Center (CCC), 222 Rosewood Drive, Danvers, MA 01923. Payment may also be made electronically through CCC Online at copyright.com. Other copying for republication, resale, advertising or promotion, or any form of systematic or multiple reproduction of any material in this book is prohibited except with permission in writing from the publisher. The CCC fee code is $1605-7422 / 16 / \$ 18.00$.

Printed in the United States of America.

Publication of record for individual papers is online in the SPIE Digital Library.

\section{SPIE. DIGITAL}

Paper Numbering: Proceedings of SPIE follow an e-First publication model. A unique citation identifier (CID) number is assigned to each article at the time of publication. Utilization of CIDs allows articles to be fully citable as soon as they are published online, and connects the same identifier to all online and print versions of the publication. SPIE uses a six-digit CID article numbering system structured as follows:

- The first four digits correspond to the SPIE volume number.

- The last two digits indicate publication order within the volume using a Base 36 numbering system employing both numerals and letters. These two-number sets start with 00, 01, 02, 03, 04, $05,06,07,08,09,0 A, 0 B \ldots$ OZ, followed by 10-1Z, 20-2Z, etc. The CID Number appears on each page of the manuscript. 


\title{
Contents
}

\author{
vii Authors \\ ix Conference Committee
}

\section{SESSION 1 PHANTOM DEVELOPMENT AND CHARACTERIZATION}

970002 National Institute of Standards and Technology measurement service of the optical properties of biomedical phantoms: current status (Invited Paper) [9700-1]

970003 Development of breast cancer tissue phantoms for terahertz imaging [9700-2]

970004 Characterization of homogeneous tissue phantoms for performance tests in diffuse optics [9700-4]

\section{SESSION 2 PRINTED PHANTOMS}

970006 Performance evaluation of CCD- and mobile-phone-based near-infrared fluorescence imaging systems with molded and 3D-printed phantoms [9700-5]

970008 Customized three-dimensional printed optical phantoms with user defined absorption and scattering [9700-7]

970009 Freeform fabrication of tissue-simulating phantoms by combining three-dimensional printing and casting [9700-8]

$9700 \mathrm{OA}$ Optical characterization of tissue mimicking phantoms by a vertical double integrating sphere system [9700-9]

\section{SESSION 3 QUALITY OF BIOMEDICAL TECHNOLOGIES}

$9700 \mathrm{OB}$ Eye safety analysis for non-uniform retinal scanning laser trajectories [9700-10]

9700 OD Quantitative assessment of hyperspectral imaging in detection of plasmonic nanoparticles: a modified contrast-detail analysis approach [9700-12]

9700 OE The component validation of direct diode 488nm lasers in BD Accuri C6 flow cytometers [9700-13]

9700 OF Dynamic thermal effects of epidermal melanin and plasmonic nanoparticles during photoacoustic breast imaging [9700-14] 
$9700 \mathrm{Ol} \quad$ Novel organosilicon phantoms as testing material for photoacoustic imaging [9700-18]

$9700 \mathrm{JJ} \quad$ Margin assessment of three-dimensional breast cancer phantoms using terahertz imaging [9700-3]

\section{SESSION $5 \quad$ BIOMEDICAL IMAGING TECHNOLOGIES I}

$970000 \quad$ Spatially resolved diffuse reflectance spectroscopy of two-layer turbid media by densely packed multi-pixel photodiode reflectance probe [9700-24]

\section{SESSION $6 \quad$ DESIGN OF BIOMEDICAL IMAGING TECHNOLOGIES}

$97000 Q \quad$ Fiber optic microprobes with rare-earth-based phosphor tips for proton beam characterization [9700-25]

9700 OR A wearable infrared video pupillography with multi-stimulation of consistent illumination for binocular pupil response [9700-26]

9700 OS Illumination-parameter adjustable and illumination-distribution visible LED helmet for lowlevel light therapy on brain injury [9700-27]

9700 OT Modelling and design of modified Wollaston prisms and the application in differential interference contrast microscopy [9700-28]

\section{SESSION 7 BIOMEDICAL IMAGING TECHNOLOGIES II}

9700 OW LED Induced Autofluorescence (LIAF) imager with eight multi-filters for oral cancer diagnosis [9700-31]

\section{SESSION 8 TRANSLATIONAL TECHNOLOGY}

970013 Spectral domain optical coherence tomography with dual-balanced detection [9700-37]

$970014 \quad$ Fast full 4x4 Mueller polarimeter for endoscopic applications [9700-39]

\section{POSTER SESSION}

970015 The role of cerebral spinal fluid in light propagation through the mouse head: improving fluorescence tomography with Monte Carlo modeling [9700-40]

970016 Towards improved image reconstruction in breast diffuse optical tomography using compressed sensing: a comparative study among Lp ( $0 \leq p \leq 2)$ sparsity regularizations [9700-41] 
970017 Validation of MTF measurement for CBCT system using Monte Carlo simulations [9700-42]

$970018 \quad$ Non-contact ECG monitoring [9700-43]

97001 A Multi-wavelength fluorescence tomography [9700-45]

9700 1B A modified laminar optical tomography system with small dip-angle and the initial validation [9700-46]

9700 1C Single-channel stereoscopic ophthalmology microscope based on TRD [9700-38] 
Proc. of SPIE Vol. $9700970001-6$

Downloaded From: https://www.spiedigitallibrary.org/conference-proceedings-of-spie on 26 Apr 2023 Terms of Use: https://www.spiedigitallibrary.org/terms-of-use 


\section{Authors}

Numbers in the index correspond to the last two digits of the six-digit citation identifier (CID) article numbering system used in Proceedings of SPIE. The first four digits reflect the volume number. Base 36 numbering is employed for the last two digits and indicates the order of articles within the volume. Numbers start with 00, 01, 02, 03, 04, 05, 06, 07, 08, 09, OA, OB...0Z, followed by 10-1Z, 20-2Z, etc.

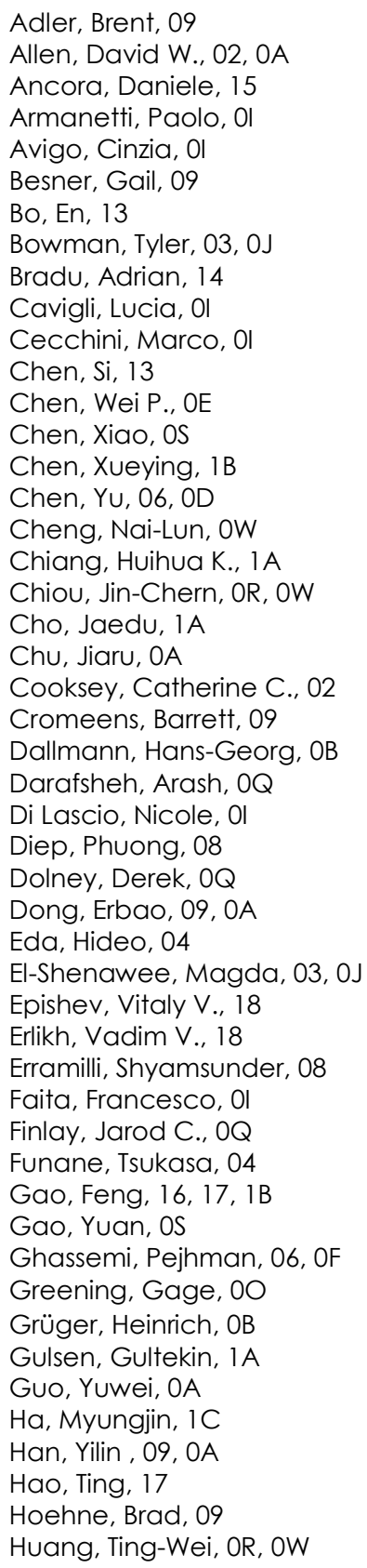

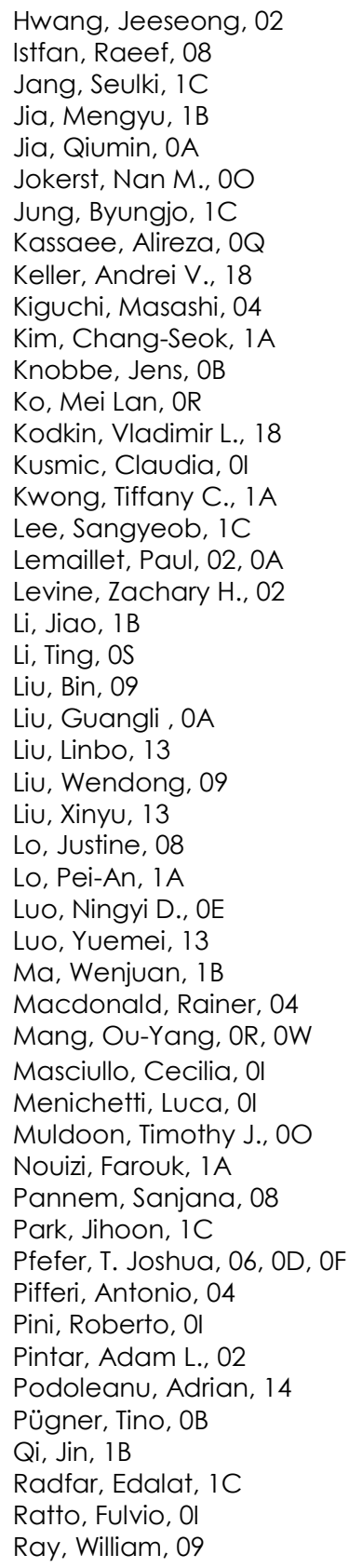


Reinig, Peter, $\mathrm{OB}$

Ripoll, Jorge, 15

Rivet, Sylvain, 14

Roblyer, Darren M., 08

Schelinski, Uwe, OB

Senlik, Ozlem, 00

Shen, Shuwei, 09, 0A

Smirnov, Alexey S., 18

Snyder, Michael, 08

Stueber, Gabriella, 08

Sweer, Jordan, 08

Tabassum, Syeda, 08

Taleei, Reza, OQ

Taubert, Dieter Richard, 04

Tian, Jing, 1B

Torricelli, Alessandro, 04

Tsai, Ming-Hsui, OW

Tsai, Yi-Chun, OR

Wabnitz, Heidrun, 04

Walter, Alec, 03, 0J

Wang, Bingyuan, 16

Wang, Bohan, 06

Wang, Haili, 09

Wang, Jianting, 06, OD

Wang, Nanshuo, 13

Wang, Pengbo, OS

Wang, Quanzeng, 06, OF

Wang, Shuang, IB

Wang, Xianghong, 13

Wang, Yihan, 16

Woittennek, Franziska, OB

Wu, Junjie, 08

Wyrowski, Frank, OT

$\mathrm{XU}$, Ronald, 09, 0A

Yu, Sungkon, $1 \mathrm{C}$

Zacharakis, Giannis, 15

Zacharopoulos, Athanasios, 15

Zhang, Site, OT

Zhang, Yanqi, 16

Zhao, Gang, OA

Zhao, Huijuan, 16, 17, 1B

Zhao, Yanyu, 08

Zhao, Zhuhua, 09

Zhong, Huiying, OT

Zhou, Ximing, OA

Zhou, Zhongxing, 17 


\section{Conference Committee}

Symposium Chairs

James G. Fujimoto, Massachusetts Institute of Technology

(United States)

R. Rox Anderson, Wellman Center for Photomedicine, Massachusetts General Hospital (United States) and Harvard School of Medicine (United States)

Program Track Chairs

Tuan Vo-Dinh, Fitzpatrick Institute for Photonics, Duke University (United States)

Anita Mahadevan-Jansen, Vanderbilt University (United States)

Conference Chairs

Ramesh Raghavachari, U.S. Food and Drug Administration (United States)

Rongguang Liang, College of Optical Sciences, The University of Arizona (United States)

Conference Co-chair

T. Joshua Pfefer, U.S. Food and Drug Administration (United States)

Conference Program Committee

David W. Allen, National Institute of Standards and Technology (United States)

Anthony J. Durkin, Beckman Laser Institute and Medical Clinic (United States)

Jeeseong Hwang, National Institute of Standards and Technology (United States)

Stephen P. Morgan, The University of Nottingham (United Kingdom)

Robert J. Nordstrom, National Institutes of Health (United States)

Jannick P. Rolland, University of Rochester (United States)

Eric J. Seibel, University of Washington (United States)

Behrouz Shabestari, National Institutes of Health (United States)

Kenji Taira, Olympus Corporation (United States)

Tomasz S. Tkaczyk, Rice University (United States)

Gracie Vargas, The University of Texas Medical Branch (United States)

Rudolf $\mathbf{M}$. Verdaasdonk, Vrije University Medical Center (Netherlands) 


\section{Session Chairs}

1 Phantom Development and Characterization

Ramesh Raghavachari, U.S. Food and Drug Administration

(United States)

Anthony J. Durkin, Beckman Laser Institute and Medical Clinic (United States)

2 Printed Phantoms

T. Joshua Pfefer, U.S. Food and Drug Administration (United States)

3 Quality of Biomedical Technologies

William C. Vogt, U.S. Food and Drug Administration (United States)

4 Phantom Technologies

David W. Allen, National Institute of Standards and Technology (United States)

5 Biomedical Imaging Technologies I

Gracie Vargas, The University of Texas Medical Branch (United States)

6 Design of Biomedical Imaging Technologies

Ramesh Raghavachari, U.S. Food and Drug Administration

(United States)

7 Biomedical Imaging Technologies II

Behrouz Shabestari, National Institutes of Health (United States)

8 Translational Technology

Rongguang Liang, College of Optical Sciences, The University of Arizona (United States)

Gracie Vargas, The University of Texas Medical Branch (United States) 